\title{
Paweł Szulc
}

\section{Czasopiśmiennictwo polskie w Iranie w latach 1942-1945}

\begin{abstract}
Abstrakt: W wyniku ustaleń układu Sikorski-Majski w 1942 r. do Iranu dotarły dwie wielkie fale Polaków - zesłańców ze Związku Radzieckiego. Żołnierzom armii gen. Andersa towarzyszyło również blisko 40 tys. cywilów. Zgodnie z założeniami mieli być jak najszybciej ewakuowani przez siły brytyjskie dalej, jednak sytuacja na frontach i problemy logistyczne powodowały, że realizacja tych planów przeciaggała się w czasie. Dla wielu Iran stał się schronieniem na parę lat. Polacy pozostawili tam po sobie bogatą spuściznę publicystyczną.
\end{abstract}

Słow a kluc z owe: Iran, uchodźcy, II wojna światowa, prasa.

Abstract: As a result of provisions of the so-called Sikorski-Majski Agreement, in 1942 two large waves of Poles exiled from the Soviet Union arrived in Iran. The soldiers of Gen. Anders' Army were accompanied by almost forty thousand civilians. According to the accepted terms, they were to be further evacuated by the British forces as soon as possible, but the situation in the war fronts and logistic problems hampered a swift implementation of these plans. For many Iran became shelter and home for several years. The Poles who were there during World War Two left a rich journalistic heritage in Iran.

Keyw ords: Iran, refugees, World War Two, the press.

Przebieg II wojny światowej spowodował, że kraje Bliskiego i Środkowego Wschodu $^{1}$ stały się na kilka lat domem i schronieniem dla tysięcy Polaków.

\footnotetext{
${ }^{1}$ Pojęcia te do dziś wywołują szereg wątpliwości, jeśli chodzi o zasięg geograficzny, zwłaszcza o przypisanie do konkretnej grupy państw Afryki Północnej, dzisiejszej Turcji czy Iranu. Więcej zob. R. Ożarowski, Bliski Wschód $w$ rozważaniach pojęciowych i geograficznych, „Gdańskie Studia Międzynarodowe” 2009, t. VII, nr 1-2, s. 115-123.
} 
Nigdy dotąd w tej części świata nie przebywało ich tak wielu. Po klęsce Francji w połowie 1940 r. pierwsze grupy Polaków ewakuowanych z Rumunii, Węgier, Jugosławii czy Grecji dotarły do Palestyny, jednak prawdziwa fala polskich uchodźców miała dopiero nadejść za niespełna dwa lata.

Atak Niemiec na Związek Radziecki w połowie $1941 \mathrm{r}$. pociagnął za sobą kluczowe konsekwencje dla Polaków wywiezionych wcześniej przez okupanta sowieckiego i rozsianych po terytorium ZSRR. Za pośrednictwem Brytyjczyków doszło do ponownego nawiązania stosunków dyplomatycznych między Polską i Związkiem Radzieckim. W wyniku niełatwych rokowań, przy jednoczesnych naciskach strony brytyjskiej, 30 VII $1941 \mathrm{r}$. podpisany został układ Sikorski-Majski². Oprócz anulowania wszelkich traktatów sowiecko-niemieckich dotyczacych granic Polski z 1939 r. układ przewidywał amnestię dla wszystkich Polaków pozbawionych wolności, a przebywających na terenie Związu Radzieckiego, otwierał także możliwość tworzenia wojska polskiego na terytorium ZSRR.

Kolejne miesiące przyniosły skomplikowane rokowania między strona polską a radziecką w sprawie szczegółów realizacji podpisanego układu. Jesienią 1941 r. w wyniku trójstronnych polsko-brytyjsko-radzieckich porozumień podjęto decyzję o ewakuacji tworzących się Polskich Sił Zbrojnych w ZSRR na Bliski Wschód. Rozpoczęły się trudne rozmowy polskiego rządu na uchodźstwie z władzami na Kremlu w sprawie skali ewakuacji, kierunku i warunków, na jakich się ona odbędzie ${ }^{3}$. Ostatecznie wiosną i latem 1942 r. miały miejsce dwie wielkie fale ewakuacji Polaków do Iranu. W ich wyniku na terenie tego państwa znalazło się ok. 116 tys. obywateli polskich, z czego ok. 70 tys. stanowiło wojsko. W'śród ludności cywilnej było ok. 20 tys. dzieci i młodzieży do 18. roku życia ${ }^{4}$.

O ile wojsko pod dowództwem gen. Władysława Andersa dość szybko zostało przerzucone do Iraku i Palestyny ${ }^{5}$, to cywile pozostali w Iranie. Plany przerzucenia ich dalej, na tereny znajdujące się pod protektoratem brytyjskim, okazały się trudne do szybkiej realizacji. Pomimo że od 1942 r. sukcesywnie przewożeni byli do Indii i brytyjskich kolonii w Afryce Wschodniej, to jednak dla tysięcy Polaków Iran stał się przejściowym domem na parę kolejnych lat.

Nikt nie wiedział, jak długo potrwa irański przystanek na szlaku polskich wychodźców. Jednocześnie, po paru latach katorgi w ZSRR, głód polskiego słowa był ogromny. Stąd też szybko zrodziły się inicjatywy powołania do życia różnego rodzaju źródeł informacji, platformy wymiany myśli i poglądów.

${ }^{2}$ E. Duraczyński, Układ Sikorski-Majski, „Dzieje Najnowsze” 1987, nr 1, s. 91-138.

${ }^{3}$ J. Pietrzak, Polscy uchodźcy na Bliskim Wschodzie w latach II wojny światowej. Ośrodki, instytucje, organizacje, Łódź 2012, s. 60-69.

${ }^{4}$ J. Wróbel, Uchodźcy polscy ze Zwiazku Sowieckiego 1942-1950, Łódź 2003, s. 12-93.

${ }_{5}^{5}$ Więcej zob. N. Davies, Szlak nadziei. Armia Andersa - marsz przez trzy kontynenty, Izabelin-Warszawa 2015. 
Już w kwietniu 1942 r., z chwilą przybycia pierwszej fali Polaków do Iranu, Poselstwo RP w Teheranie rozpoczęło wydawanie „Komunikatu Radiowego dla Uchodźców Polskich w Teheranie". Redagował go dr Wiktor Weintraub. Nie była to jeszcze gazeta z prawdziwego zdarzenia. „Komunikat” drukowano, następnie wywieszano we wszystkich obozach i odczytywano publicznie, by treści dotarły do jak najszerszego grona. Pamiętać należy, że część polskich wychodźców była niepiśmienna.

Spośród regularnie wydawanych periodyków najszybciej pojawiły się pisma wojskowe. Pierwszym z nich był tygodnik Samodzielnego Referatu Kulturalno-Oświatowego Dowództwa Bazy Ewakuacyjnej „Zew”, którego nr 1 ukazał się w czerwcu 1942 r., ostatni zaś cztery miesiące później. Pismo było redagowane przez Eugenię Duszyńską ${ }^{6}$, a także por. Władysława Ludwika Everta i mjr. Ludwika Naimskiego. Łącznie ukazało się 18 numerów gazety.

W pierwszym numerze redakcja zapowiadała, że cel pisma stanowi przygotowanie wszystkich do wspólnego wysiłku w celu odzyskania niepodległości. „Zew to zawołanie - byśmy stali się lepszymi - ku chwale Polski?” - pisano. W związku z tym, że wydawcą było wojsko, większość materiałów publikowanych w tygodniku stanowiły zagadnienia związane z sytuacją na frontach, życiem polskich żołnierzy na Bliskim Wschodzie czy sytuacja w okupowanej Polsce. Tygodnik „Zew” posiadał jeszcze jedną wyróżniająca go cechę. W żadnym innym periodyku wydawanym w Iranie nie umieszczano tak wielu reklam. Na łamach tygodnika reklamowały się polskie domy komisowe, zakłady krawieckie, pralnie chemiczne, perfumerie, wreszcie restauracje. Niektóre przyciagały klientów wizją zacienionych ogrodów, występami orkiestry, obiadami z czterech dań czy zniżkami „specjalnie” dla Polaków. Reklamy te stanowią bezcenne świadectwo życia codziennego Polaków żyjących wówczas w Teheranie.

Należy też wspomnieć o krótkim irańskim epizodzie w historii „Orła Białego”. Pierwszy numer wydawanego przez Wojskowe Biuro Propagandy i Oświaty Polskich Sił Zbrojnych w ZSRR periodyku ukazał się 7 XII $1941 \mathrm{r}$. w Buzułuku w Związku Radzieckim. Wraz z rozwojem sytuacji na frontach II wojny światowej i przemieszczaniem się polskich żołnierzy na zachód zmieniały się miejsca wydawania pisma ${ }^{8}$.

\footnotetext{
${ }^{6} \mathrm{~W}$ swoich wspomnieniach zaledwie napomyka ona o epizodzie pracy w dowództwie Polskich Sił Zbrojnych i redagowaniu tygodnika „Zew”. Więcej zob. E. Huntingdon, Nie wyrównany rachunek. Wspomnienia, Warszawa 1994, s. 233.

7 Notka redakcyjna, „Zew”, 25 VI 1942.

${ }^{8}$ Więcej o początkach pisma zob. Z. Racięski, Pisklęce lata „Orta Biatego”, „Zeszyty Historyczne” (Paryż) 2001, z. 138, s. 146-152; J. Święch, Literatura polska w latach II wojny światowej, Warszawa 2000, s. 307-309; K. Walaszczyk, Środkowy Wschód w latach II wojny światowej. Relacje i działania polskich placówek dyplomatycznych i konsularnych $w$ Iranie, Iraku i Afganistanie, Toruń 2012, s. 236.
} 
Z polską armią pismo trafiło także do Iranu, gdzie ukazały się dwa numery redagowane przez Romana Hausnera ${ }^{9}$. Zaledwie dwa, ponieważ żołnierze szybko zostali przetransportowani dalej, do Iraku i Palestyny. Wypada uznać, że były to jednak historyczne numery, ponieważ jako pierwsze ukazały się poza granicami Związku Radzieckiego, kiedy Polskie Siły Zbrojne z ZSRR połączyły się Wojskiem Polskim na Środkowym Wschodzie, tworząc dowodzona przez gen. Andersa Armię Polską na Wschodzie. We wrześniowym numerze pisma przedrukowano rozkaz generała wyjaśniajacy utworzenie Armii Polskiej na Wschodzie, tłumaczył także żołnierzom strategiczne położenie Iranu i Bliskiego Wschodu, na którego terenie przyszło im się znaleźć ${ }^{10}$.

Grupę pism wojskowych uzupełniaja „Teherańskie Fraszki dla Żołnierskiej Igraszki”, które de facto pismem nie były, lecz gazetką ścienną. Taka forma wydawnictw pojawiła się już w $1941 \mathrm{r}$. w Buzułuku i została bardzo dobrze przyjęta przez żołnierzy, którzy zaczęli rywalizować w wykonaniu, estetyce i doborze treści do tych gazetek. Wszystko odbywało się pod kontrolą Biura Propagandy i Kultury. Teksty najczęściej pisali Ignacy Jeśman i Tadeusz Wittlin, natomiast ilustracje przygotowywał Włodzimierz Kowańko ${ }^{11}$.

Bez wątpienia najważniejszym tytułem, który ukazywał się w tym czasie w Iranie, był tygodnik wydawany początkowo przez Delegaturę Rządu RP, następnie Delegaturę Ministerstwa Opieki Społecznej, wreszcie Delegaturę Ministerstwa Pracy i Opieki Społecznej (MPiOS), pt. „Polak w Iranie”. Ukazywał się w każdą sobotę (choć z datą niedzielna) od czerwca 1942 r. do maja 1944 r., kiedy to ewakuowano redakcje do Afryki. Gazeta drukowana była w dużym formacie, w objętości od 2 do 10 stron, do numeru 75 bez polskich czcionek.

Pismo miało charakter ogólnoinformacyjny. Oferowało kompendium wiedzy o życiu Polaków w Iranie, sytuacji na frontach, polityce władz emigracyjnych i życiu w okupowanej Polsce. Publikowane były m.in. felietony prezentujące życie Polaków w irańskich obozach. Choć w Teheranie obozów było najwięcej, to szczególne miejsce przypadło Isfahanowi, w którym przebywało kilka tysięcy polskich dzieci ${ }^{12}$. Opisywano w tygodniku organizację obozu, życie codzienne dzieci i prowadzoną tam działalność edukacyjna ${ }^{13}$. Pisano

${ }_{9}$ O.S. Czarnik, W drodze do utraconej Itaki. Prasa, ksiażki i czytelnictwo na szlaku Samodzielnej Brygady Strzelców Karpackich (1940-1942) oraz Armii Polskiej na Wschodzie i 2. Korpusu (1941-1946), Warszawa 2012, s. 81-84.

10 W Iranie, „Orzeł Biały”, 20 IX 1942.

11 J. Czapski, Relacja o pracy Biura Propagandy i Kultury w 1942 r., „Zeszyty Historyczne” (Paryż) 2001, z. 138, s. 153-154.

12 Więcej zob. Isfahan. Miasto polskich dzieci, red. I. Beaupré-Stankiewicz, D. Waszczuk-Kamieniecka, J. Lewicka-Howells, Londyn 1987.

${ }_{13}$ Zob. m.in.: P. Pialuha, Isfahan. Ośrodek najmłodszej emigracji polskiej, „Polak w Iranie” 1942, nr 4; B., Bilans szkolnictwa polskiego w Iranie, „Polak w Iranie” 1942, nr 24; M. Piołun, Pochwała Isfahanu, „Polak w Iranie” 1943, nr 26. 
o nowych transportach uchodźców polskich do obozów, opiece lekarskiej nad chorymi. Informowano o kursach dokształcajacych, występach artystycznych, prowadzonych odczytach, wystawach malarskich, a także codziennej pracy wykonywanej przez Polaków ${ }^{14}$. Na łamach pisma umieszczano też relacje z obchodów rocznic i oficjalnych świąt państwowych.

Ponieważ Delegatura MPiOS w Teheranie odpowiedzialna była za plan przygotowania ewakuacji Polaków z Iranu, jej organ prasowy - „Polak w Iranie” - wiele miejsca poświęcał tej kwestii. Na łamach tygodnika prezentowano zarządzenia ewakuacyjne, przedstawiano relacje z podróży do brytyjskich kolonii w Afryce, do Indii, Meksyku, a także opisywano życie Polaków, osiedlanych już w nowych miejscach.

Niekiedy podawane na łamach pisma informacje były nieprecyzyjne. Przykładowo pod koniec 1943 r. w Teheranie miało miejsce pierwsze spotkanie przywódców Stanów Zjednoczonych, Wielkiej Brytanii i Związku Radzieckiego. Nieuczestniczący w naradzie Polacy nie mogli wiedzieć, jak ważne dla przyszłości Polski decyzje już wówczas zapadły. Bliskość miejsca obrad w stosunku do usytuowania redakcji „Polaka w Iranie” nie miała jednak żadnego znaczenia. Redakcja opublikowała tylko tyle, co mogła wyczytać z oficjalnego komunikatu. Ponieważ operował on - co zrozumiałe ze strategicznego punktu widzenia - ogólnikami i jednocześnie koncentrował się na potrzebie jak najszybszego zakończenia wojny, „Polak w Iranie” doszedł do błędnego założenia, że o sprawach polskich w ogóle nie rozmawiano. „Ci, którzy od konferencji oczekiwali konkretnych rozstrzygnięć w szeregu naszych spraw, nie mieli i nie mogli mieć racji. [...] Konferencja mocarstw, która musiała decydować o sprawach globu, nie mogła zajmować się poszczególnymi problemami świata i Europy"15.

Tygodnik miał stałe rubryki. „Terror w Polsce” przynosił krótkie informacje z życia w okupowanym kraju, o mordach na Żydach, powstawaniu nowych obozów koncentracyjnych, polityce germanizacyjnej, represjach stosowanych przez Niemców, poborze do niemieckiej armii, prześladowaniach religijnych, ale także sytuacji aprowizacyjnej i problemach codziennej egzystencji. „Kronika Tygodniowa" informowała natomiast o bieżacej sytuacji na frontach II wojny światowej ${ }^{16}$.

Fakt, że dzieci i młodzież stanowiły około połowę grupy polskich wychodźców, musiał znaleźć swoje odbicie w „Polaku w Iranie”. Temat życia dzieci w irańskich obozach, ich edukacji, rozrywek i opieki nad nimi poruszany był niemal w każdym numerze. Niezależnie od tego redakcja gazety przygotowała

\footnotetext{
${ }_{14}$ Zob. m.in.: Praca $w$ naszych obozach. Szwalnia - warsztaty trykociarskie - pracownia artystyczna, „Polak w Iranie” 1942, nr 24.

${ }_{15}$ M.T., Konferencja „Wielkiej Trójki” $w$ Teheranie, „Polak w Iranie” 1943, nr 74.

${ }_{16}$ Zob. m.in.: T.E., Klęska Osi w Afryce, „Polak w Iranie” 1942, nr 19; Ofensywa rosyjska na froncie południowym, „Polak w Iranie” 1943, nr 29.
} 
dla najmłodszych specjalny dodatek. W „Gazetce dla Dzieci”, zastapionej przez „Gazetkę dla Młodzieży”, prezentowano wiersze, bajki i opowiadania, a także fragmenty prozy polskich klasyków - Henryka Sienkiewicza, Bolesława Prusa, Stefana Żeromskiego ${ }^{17}$. Dodatkowo, w związku z brakiem podręczników i niezbędnych pomocy naukowych, w „Polaku w Iranie” dodrukowywano opracowywaną przez nauczycielską komisję redakcyjną wkładkę zawierająca materiały szkolne dla klas I-III ${ }^{18}$.

Pismo stanowiło także kompendium wiedzy o miejscu, w którym Polakom przyszło żyć. Pisano o klimacie Iranu, jego geografii, infrastrukturze, ale także o bieżących problemach gospodarczych i aprowizacyjnych w państwie. Sporo miejsca poświęcano historii i kulturze Persji, a także relacjom Polski i Persji w przeszłości ${ }^{19}$. Jednocześnie informowano o wszelkich inicjatywach mających przybliżyć historię i kulturę Polski Irańczykom, tj. odczytach na Uniwersytecie Teherańskim, audycjach w radiu teherańskim czy wydawnictwach publikowanych w języku francuskim lub farsi.

7 V 1944 r. ukazał się ostatni, 95 numer „Polaka w Iranie”. Redakcja dziękowała za współpracę, przepraszała za wszelkie możliwe niedociagnięcia lub błędy i tłumaczyła decyzję o zamknięciu tytułu rozpoczęciem ostatniej fazy ewakuacji Polaków z Iranu. Żegnano się słowami: „Do rychłego widzenia się w wolnej i niepodległej Polsce"20.

Ważną pracę informacyjną wykonywał w Teheranie Jerzy Lenczowski. Był absolwentem prawa na Uniwersytecie Warszawskim i Uniwersytecie Paryskim. Jeszcze przed wojną obronił we Francji doktorat i rozpoczął pracę jako urzędnik konsularny w Brytyjskim Mandacie Palestyny, gdzie pełnił rolę łącznika między władzami brytyjskimi a żydowskimi imigrantami docierającymi do Palestyny z Polski. Wstapił jako ochotnik do wojska, brał udział w walkach w północnej Afryce, ale pod koniec 1940 r. Ministerstwo Spraw Zagranicznych skierowało go do Teheranu, powierzając mu funkcję attaché prasowego przy Poselstwie RP w Iranie. Funkcję tę pełnił do 1945 r., kiedy wyjechał do Stanów Zjednoczonych, gdzie kontynuował karierę naukową ${ }^{21}$. W Iranie przygotowywał wydawane $\mathrm{w}$ obcych językach pisma traktujące o sprawach polskich: w języku farsi „Name-je-Lechistani”, w języku angielskim „Polish News Bulletin” i w języku francuskim „La Nouvelle Europe” oraz „Bulletin

${ }_{17}$ Więcej o tym zob. M. Ney-Krwawicz, „Polak w Iranie” o młodych i najmłodszych uchodźcach polskich $z$ ZSRR $w$ Iranie $w$ latach 1942-1944, „Dzieje Najnowsze” 2014, nr 1, s. 85-110.

18 J. Draus, Oświata i nauka polska na Bliskim i Środkowym Wschodzie 1939-1950, Lublin 1993, s. 89.

19 Zob. m.in.: F. Machalski, Ispahan - połowa świata. Wspomnienie z wycieczki, „Polak w Iranie" 1944, nr 79.

${ }^{20}$ Do naszych czytelników, „Polak w Iranie” 1944, nr 95.

${ }^{21} \mathrm{~W}$ jego pracach problematyka Iranu i Bliskiego Wschodu była stale obecna. Zob. m.in.: G. Lenczowski, Iran under the Pahlavis, Stanford 1978; idem, The Middle East in World Affairs, Ithaca 1980; idem, American Presidents and the Middle East, Durham (N.C.) 1990. 
D'Information". Zaciekawienie budzi przede wszystkim pierwszy tytuł, z winietą i całymi stronami zapełnionymi drobnym, całkowicie obco wygladającym alfabetem, datą wydania napisaną alfabetem perskim, a na pierwszej stronie artykułem o Konstytucji 3 maja zilustrowanym godłem Polski ${ }^{22}$.

Oficjalne stanowisko władz polskich przedstawiał kopiowany początkowo na maszynie do pisania „Komunikat Poselstwa RP w Teheranie”, który następnie został zamieniony na „Komunikat Poselstwa”. Ten wydawany codziennie biuletyn redagowany był kolejno przez Wiktora Weintrauba, Leona Kryja i Michała Tyszkiewicza.

Działajace w Iranie ugrupowania polityczne miały ambicje wydawania swoich periodyków. Wspominany już wcześniej „Polak w Iranie” choć formalnie nie był pismem żadnej partii, to jednak z faktu, że został zdominowany przez socjalistów Ministerstwa Pracy i Polityki Społecznej, nieformalnie traktowano go jako gazetę PPS ${ }^{23}$. Ludowcy - pomimo że z ich szeregów wywodził się tak prominentny polityk, jak dr Karol Bader, który w Iranie pełnił funkcję posła i ministra pełnomocnego RP - nie mieli w Iranie swojego organu prasowego. W czerwcu 1943 r. z okazji Święta Ludowego wydali jednodniówkę pt. „Chłop i Państwo", w której zapewniali, że mimo tragicznej sytuacji, w której znalazły się tysiące chłopów poza granicami kraju, ich ideały przetrwały i przetrwaja. „We wskrzeszonej Polsce zbuduje [chłop - P.S.] mocny, przestrzenny i słoneczny gmach Najjaśniejszej Rzeczypospolitej, w której będzie miał należne sobie miejsce" - zapowiadano. W styczniu 1945 r. wyszła kolejna jednodniówka Stronnictwa Ludowego (SL), w której umieszczono m.in. list do prezesa PSL Stanisława Mikołajczyka ${ }^{24}$.

Zwolennicy sanacji, opozycyjni wobec PPS i SL, zgrupowali się w Zespole Pracy nad Odbudowa Polski. Przewodniczacym powstałego jesienia 1942 r. ugrupowania był attaché Poselstwa RP w Teheranie hr. Michał Tyszkiewicz, który namówił do przystapienia do tej konserwatywnej organizacji Konstantego Rdułtowskiego, przedwojennego posła i senatora z ramienia Bezpartyjnego Bloku Wspierania Reform ${ }^{25}$. Zanim przygotowano swój periodyk, jesienia 1942 r. Zespół Pracy nad Odbudową Polski wydał jednodniówkę, w której zaprezentował m.in. swoje główne założenia ideologiczne. Pisano o konieczności walki o odbudowę państwa polskiego, państwa, w którym władza będzie miała silny autorytet, państwa o ustroju demokracji parlamentarnej, państwa, które odgrywać miałoby po wojnie kluczową rolę w rejonie Europy Środkowo-Wschodniej ${ }^{26}$.

\footnotetext{
${ }^{22}$ Archiwum Akt Nowych (dalej: AAN), Towarzystwo Studiów Irańskich, „Name-je-Lechistani”, 9 V 1943.

${ }^{23}$ K. Walaszczyk, Działalność Stronnictwa Ludowego wśród uchodźców polskich w Iranie w latach 1942-1945, „Zeszyty Wiejskie” 2011, z. 16, s. 83-84.

${ }^{24}$ Polacy w Iranie 1942-1945, t. I: Antologia, oprac. A.K. Kunert, Warszawa 2002, s. 281, 536.

${ }^{25}$ K. Rdułtowski, Notatki z wygnania, oprac. S. Ciesielski, Warszawa-Wrocław 1996, s. 131-133.

${ }^{26}$ Punkty wytyczne, „Zespół Pracy nad Odbudową Polski. Jednodniówka”, 22 XI 1942.
} 
$\mathrm{Na}$ Konstantym Rdułtowskim spoczął obowiązek przygotowywania początkowo „Biuletynu”, a następnie oficjalnego organu prasowego Zespołu Pracy, pt. „Przegląd Polski”. Miesięcznik ten nie miał dużego oddziaływania. Ukazały się zaledwie trzy numery na początku 1943 r. Pismo wydawane było w Teheranie, ale starano się je rozprowadzać również na terenie Iraku ${ }^{27} . \mathrm{Na}$ jego łamach miejsce znajdowały także przedruki z innych periodyków. Tak było w wypadku artykułu Stanisława Świaniewicza z wychodzacej w Jerozolimie „Gazety Polskiej”. Profesor pisał o wielkiej roli, jaka Polska powinna po wojnie odegrać. Wskazywał, że tak jak Jerozolima na Bliskim Wschodzie jest miastem świętym, tak Wilno po wojnie powinno się stać „[...] ważnym ośrodkiem promieniowania polskiego ducha"28. Czas pokazał, jak bardzo płonne były te nadzieje.

W 1943 r. ukazały się w Iranie dwa numery miesięcznika naukowo-społecznego, pt. „Polska Nowojagiellońska”. Redagowane przez Tadeusza Dzieduszyckiego pismo nie jest łatwe w odbiorze i zdecydowanie wymyka się prostej ocenie. Wszystko za sprawą samego redaktora, który łączył w sobie patriotyczny etos, powagę $\mathrm{w}$ kwestii spraw narodowych $\mathrm{z}$ umysłowościa utopijna prezentująca mocno niekonwencjonalne wizje programowe ${ }^{29}$. Pismo wsławiło się jeszcze tym, że jego ekstremistyczne zabarwienie doprowadziło do konfiskaty ostatniego numeru.

Stronnictwo Narodowe (SN) wydawało redagowane przez Stefana Brosia „Słowo Polskie”. Pierwszy numer tego wyjątkowo starannie i estetycznie wydawanego miesięcznika ukazał się w grudniu $1942 \mathrm{r}$. Przy winiecie pisma znajdowały się słowa Romana Dmowskiego: „Polakiem jestem, nic co polskie nie jest mi obce”. SN występowało zdecydowanie przeciwko działającym w Iranie PPS, Delegaturze MPiOS czy ludowcom, niemniej na łamach swojego periodyku starano się tchnać ducha optymizmu w czytelników, nie pogłębiając politycznych podziałów. „[...] Chociaż my Polacy rozproszeni jesteśmy po świecie, jak liście burzą miotane, to jednak stanowimy całość mocna, zwarta, jedna jedyną przepojona myśla o powrocie do Polski niepodległej, wielkiej, potężnej, sprawiedliwej"30. Ten tytuł prasowy wsławił się tym, że jego dwa numery, z połowy grudnia 1942 r. i lutego 1943 r., zostały skonfiskowane przez władze radzieckie. Wiosna $1943 \mathrm{r}$. podjęto decyzję o wstrzymaniu wydawania pisma z powodu - jak to określono: „wprowadzenia ostatnio w Teheranie dla

${ }^{27}$ O.S. Czarnik, $W$ drodze do utraconej..., s. 342-343.

28 S. Świaniewicz, Jeruzalem Litwy, „Przegląd Polski” 1943, nr 3.

${ }_{29}$ Tadeusz Dzieduszycki z Iranu wyjechał do Palestyny, gdzie opublikował broszury pod charakterystycznymi tytułami: Święty Legion, Narodowojagielloński Grunwald Intelektualny czy $O$ Trzeci Wzlot Narodu Wielkiej Szarży. Działał następnie w środowisku emigracyjnym w Londynie, jednak nie był poważnie traktowany przez polski establishment emigracyjny. Więcej na temat tej postaci zob. P. Chojnacki, Mesjanizm Drugiej Wielkiej Emigracji. Wielkopolski, Dzieduszycki i Nałęcz, „Pressje” 2012, t. XXX/XXXI, s. 71-86.

30 „Słowo Polskie”, 15 XII 1942, nr 1. 
czasopism polskich również cenzury sowieckiej" ${ }^{31}$. W maju 1943 r. ukazała się też jednodniówka SN, pt. „Salus Reipublicae Suprema Lex”32.

Odrębna grupę periodyków stanowiły pisma przygotowywane z myśla o uczącej się w Iranie rzeszy dzieci i młodzieży lub te opracowywane przez nich samych. W Teheranie szybko rozpoczęła działalność Delegatura Urzędu Oświaty i Spraw Szkolnych. Z niemałymi kłopotami zaczęto organizować pierwsze szkoły powszechne i średnie ${ }^{33}$.

Pierwszym wydawnictwem przygotowanym przez Zwiąek Nauczycielstwa Polskiego była jednodniówka „Nauczyciel i Uczeń w Iranie”. W starannie zredagowanym, wzbogaconym materiałem fotograficznym, wydawnictwie redakcja przypominała trudne początki organizacji szkolnictwa $\mathrm{w}$ Iranie. Wspominano pierwsze klasyfikacje dzieci, kompletowanie grup, rozdział pracy pomiędzy wychowawców, brak jakichkolwiek pomocy dydaktycznych, programów nauczania, a także niezwykłe warunki, w jakich przyszło początkowo prowadzić zajęcia, tj. płytę nieczynnego lotniska w Teheranie, siedzenia układane przez dzieci $\mathrm{z}$ cegieł, tablice na piasku itp. ${ }^{34} \mathrm{~W}$ jednodniówce nie zabrakło także wspomnień samych dzieci. Dzieliły się one wrażeniami z powrotu do nauki, pisały też, jak radzą sobie z odrabianiem lekcji.

W Isfahanie, który stał się schronieniem dla paru tysięcy polskich dzieci, w 1945 r. Zrzeszenie Nauczycieli Polaków wydawało krótko miesięcznik „Szkoła na Obczyźnie”. W pierwszym numerze, który ukazał się w kwietniu 1945 r., redakcja zdradzała ambitne plany i zamierzenia, jakie stawiała przed sobą. Według twórców pismo miało być łącznikiem pomiędzy rozproszonym po świecie nauczycielstwem polskim, stanowić platformę do wymiany myśli i doświadczeń pedagogicznych i zawodowych nauczycieli. O ile pomysł uznać należy za słuszny i potrzebny, to jednak lektura pierwszego numeru nie dawała nadziei, że uda się go zrealizować, pomijając całkowicie kwestie dystrybucji pisma. W inauguracyjnym numerze znalazły się informacje o życiu

${ }^{31}$ Polacy $w$ Iranie 1942-1945..., s. 230, 246.

32 Jako miejsce wydania podany był Bagdad, jednak analiza czcionek drukarskich pozwoliła ustalić, że jednodniówkę wydrukowano w teherańskiej drukarni SN „Słowo Polskie”. Świadome wprowadzenie w błąd mogło być owocem wcześniejszych doświadczeń z cenzura sowiecką w Teheranie. Zob. ibidem, s. 274.

${ }^{33} \mathrm{O}$ szkolnictwie polskim w Iranie zob. m.in.: J. Draus, Oświata i nauka polska...; K. Śliwak, Delegatura Ministerstwa Pracy $i$ Polityki Spotecznej $w$ Teheranie w latach II wojny światowej - charakterystyka działań edukacyjnych dla polskich uchodźców, „Ogrody Nauk i Sztuk” 2015, nr 5, s. 261-268; M.A. Supruniuk, Nauka polska na Bliskim i Środkowym Wschodzie w latach 1942-1949, „Opuscula Musealia” 2014, z. 22, s. 45-71; E. Sadowska, Losy polskiej szkoty na obczyźnie (1940-1947), „Zeszyty Historyczne. Prace Naukowe Akademii im. Jana Długosza w Częstochowie” 2010, t. XI, s. 471-481; A. Kantecki, Szkolnictwo polskie $w$ Iranie $w$ latach II wojny światowej, „Nadwarciański Rocznik Historyczno-Archiwalny" 2003, nr 10, s. 139-146.

${ }^{34}$ P. Pialucha, Narodziny szkoty polskiej $w$ Iranie, „Nauczyciel i Uczeń w Iranie. Jednodniówka Związku Nauczycielstwa Polskiego”, Teheran 1944. 
religijnym Polaków w Isfahanie, organizacji przedszkola polskiego w tym mieście, a także krótka notka o funkcjonowaniu Zrzeszenia Nauczycieli Polaków. Gros miejsca, bo ok. 7 stron na 19, zajął tekst o organizacji szkolnictwa w Anglii, niemający nic wspólnego z funkcjonowaniem polskich ośrodków nauczycielskich na emigracji ${ }^{35}$. Innym zupełnie nietrafionym pomysłem było opublikowanie artykułu o znaczeniu użytkowania złóż torfowych w rozwoju gospodarczym Polski.

Znacznie ciekawiej prezentowała się gazetka opracowywana przez uczniów liceum i gimnazjum w Isfahanie ${ }^{36}$. Periodyk „My” przygotowywany był na zwykłej maszynie do pisania i odbijany na powielaczu, jednak młodzi redaktorzy zadawali sobie nieco trudu, aby go ręcznie zilustrować. Obok tej prostej, ale estetycznej formy uwagę zwraca fakt, że wykorzystano maszynę z polskimi czcionkami, co było rzadkością wśród polskich gazet w Iranie. Pierwszy numer ukazał się w czerwcu 1943 r., ostatni w marcu 1945 r. Na łamach pisma uczniowie prezentowali m.in. życiorysy prezydenta Władysława Raczkiewicza, gen. Władysława Sikorskiego czy gen. Władysława Andersa. Pisali o przyjeździe do Persji, o założeniu drużyny harcerskiej, wyprawach rowerowych i wycieczkach do meczetów. Duże wrażenie w życiu dzieci i młodzieży wywołało otwarcie basenu, który stał się wielką atrakcja dla najmłodszych ${ }^{37}$. W numerze wielkanocnym $1944 \mathrm{r}$. uczniowie dzielili się $\mathrm{z}$ jednej strony wspomnieniami świąt spędzanych $\mathrm{w}$ domach rodzinnych jeszcze przed wybuchem II wojny światowej, z drugiej przypominali, jak te same święta wyglądały na zsyłce w Związku Radzieckim ${ }^{38}$.

Na przełomie lutego i marca 1945 r. w Isfahanie miał miejsce pierwszy i jedyny egzamin dojrzałości, do którego podeszło 12 pań. Wszystkie zdały maturę, w tym 6 z nich z wynikiem bardzo dobrym. Z tej okazji wydały dość obszerna, 34-stronicową jednodniówkę, pt. „Ze wspomnień naszej klasy”39.

Wiosna 1944 r. został opublikowany pierwszy numer pisma młodzieży polskiej w Iranie, zatytułowany „Demawend” (tytuł nawiązywał do najwyższego szczytu Iranu). W założeniu pismo miało ukazywać się dwa razy w miesiącu, ostatecznie wydano tylko trzy numery. Redakcja wychodziła ze słusznego założenia, że w czasie wojny, przebywając tysiące kilometrów od domów rodzinnych i ojczyzny, najmłodszym czytelnikom należy się chwila wytchnienia i rozrywki, aby bawiąc się, jednocześnie mogli nauczyć się

\footnotetext{
${ }^{35}$ J. Ryder, Education in England, „Szkoła na Obczyźnie. Organ Zrzeszenia Nauczycieli Polaków w Iranie", 25 IV 1945.

${ }^{36}$ Skład redakcji zmieniał się w poszczególnych numerach. Redaktorami odpowiedzialnymi byli dyrektor gimnazjum Mieczysław Kotlicki i nauczycielka języka polskiego Halina Zięciakowa. Zob. Isfahan. Miasto polskich dzieci..., s. 200-201.

37 J. Koziarz, Na basenie, „My. Czasopismo Młodzieży Liceum i Gimnazjum”, 27 XI 1943.

${ }^{38}$ Por. I. Juchniewicz, Wielkanoc na zsytce, D. Misiak, Wielkanoc w Polsce, „My. Czasopismo Młodzieży Liceum i Gimnazjum", 1 V 1944.

${ }^{39}$ Isfahan. Miasto polskich dzieci..., s. 198-200.
} 
czegoś. Już w pierwszym numerze przedrukowano wiersz Marii Konopnickiej, pt. Ojczyzna, w przystępnej historyjce przedstawiono specyfikę działania państwa podziemnego $\mathrm{w}$ okupowanym kraju ${ }^{40}$, ale także prezentowano zwyczaje perskie związane z przypadajacym na równonoc wiosenna nowym rokiem w Iranie. W kolejnych dwóch numerach ukazywano dzieciom trudne życie ich rówieśników pod okupacją w kraju, organizowanie tajnych kompletów i specyfikę obchodzenia świąt w czasie wojny. Pracujący w Iranie jeden z ludowców Mikołaj Jerzy Górszczyk wspominał, że w związku $\mathrm{z}$ istniejacymi $\mathrm{w}$ łonie wychodźstwa irańskiego sporami politycznymi wydawany przez Zarząd Zrzeszenia Nauczycieli Polaków „Demawend” był niestety bojkotowany przez dyrektora gimnazjum i niektórych kierowników poszczególnych zakładów ${ }^{41}$.

Już w 1940 r. na terenie Syrii, następnie w Palestynie utworzyły się pierwsze grupy harcerskie. W październiku 1941 r. w Tel Awiwie odbyła się I Konferencja Harcerska na Bliskim i Środkowym Wschodzie, która uznając zwierzchnictwo Naczelnego Komitetu Związku Harcerstwa Polskiego (ZHP) w Wielkiej Brytanii, ogłosiła się najwyższą władzą harcerską w tej części świata. Swoim zasięgiem objęła w późniejszym czasie także wszystkie struktury, które utworzyły się w Iranie ${ }^{42}$. W stosunkowo nudnym i ubogim życiu uchodźczym harcerstwo stanowiło dla wielu młodych ludzi prawdziwą atrakcję. $\mathrm{Z}$ tego powodu zdecydowana większość, bo $80-90 \%$ dzieci i młodzieży, należała do organizacji harcerskiej lub zuchowej ${ }^{43}$. Najważniejszym periodykiem, który ukazywał się w latach 1942-1946, był „Skaut. Czasopismo Związku Harcerstwa Polskiego na Bliskim Wschodzie”, już w podtytule wskazujący trzy miejsca pobytu Polaków: Palestyna, Irak, Iran ${ }^{44}$.

Swoim tytułem pismo nawiąało do przedwojennych, lwowskich tradycji wydawniczych harcerstwa polskiego. Redaktorem naczelnym był hm. Jeremi Śliwiński, komendant ZHP na Wschodzie, którego w 1945 r. zastapił dh Stanisław Panek. Pierwszy numer ukazał się na przełomie listopada i grudnia 1942 r. w Jerozolimie, ostatni zaś cztery lata później w tym samym mieście. Początkowo wychodzący średnio raz na dwa miesiące periodyk obejmował swoim zasięgiem właśnie Palestynę, Irak i Iran, z czasem jednak jego

${ }^{40}$ M.L. Ponikowska, Wojsko bez mundurów, „Demawend” 1944, nr 1.

${ }^{41}$ M.J. Górszczyk, Szkice emigracyjne. Rumunia. Iran. Palestyna. Egipt, Warszawa 1948, s. 54.

${ }^{42}$ Więcej zob. Dzieje harcerstwa na obczyźnie w latach 1912-1992. Materiaty z konferencji naukowej odbytej $w$ dniach 29-30 maja 1992 r. w Rogach k. Gorzowa Wlkp., red. M. Szczerbiński, Gorzów Wielkopolski 1992; T. Truchanowicz, Zwiazek Harcerstwa Polskiego na Wschodzie. Z dziejów harcerstwa na obczyźnie 1940-1946, Warszawa 1987.

${ }^{43}$ M. Wierzbicki, Zwiazek Harcerstwa Polskiego działajacy poza granicami kraju jako przedmiot badań naukowych, w: Emigracyjne miscellanea. Studia z dziejów polskiej emigracji politycznej 1939-1990, red. S. Łukasiewicz, Warszawa 2017, s. 258.

${ }^{44}$ W. Kukla, Skaut. Czasopismo Zwiazku Harcerstwa Polskiego na Wschodzie 1942-1946, „Skaut. Harcerskie Pismo Historyczne” 2007, nr 3, s. 6-10. 
oddziaływanie zostało rozszerzone o Indie, Egipt, Syrię i Afrykę Wschodnia, a w ostatnim roku także Australię i Nową Zelandię ${ }^{45}$.

Natomiast w samym Iranie w styczniu 1944 r. ukazał się „Wódz Zuchów. Jednodniówka Wodzów Gromad Zuchowych". Redaktorem był kierownik Wydziału Zuchowego ZHP na Wschodzie hm. Zdzisław Peszkowski. Jednodniówka wzbogacona została zdjęciami i odręcznymi rysunkami, za które odpowiadała wędrowniczka Czesława Ogrodnik. Zgodnie z tytułem pismo przeznaczone było dla wychowawców. Znalazły się tam informacje pomocne w przygotowaniu pracy z zuchami, pracy „kręgu wodzów zuchowych”, uzyskiwaniu określonych sprawności czy przykłady zajęć z majsterkowania również dla dziewcząt ${ }^{46}$.

Do prasy religijnej należy zaliczyć przede wszystkim ukazujący się w latach 1942-1944 dwutygodnik „Nasz Przyjaciel”. Gazeta przygotowywana była przez Wydawnictwo Duszpasterstwa Katolickiego w Iranie, dzięki wsparciu Stolicy Apostolskiej. W Iranie wydano w sumie 41 numerów. W piśmie, które według założeń miało być „pokarmem duchowym” dla przebywających w Iranie katolików, publikowano modlitwy i fragmenty ewangelii, wyjaśniano znaczenie poszczególnych przykazań i przypominano o obowiązkach religijnych osób wierzących ${ }^{47}$. Nakład pisma nie mógł być zbyt duży, ponieważ redakcja apelowała, aby egzemplarze przekazywać kolejnym czytelnikom. „Wskazanem jest - dodawano także - szanowanie i zbieranie tych ulotek, celem przewiezienia ich do Ojczyzny na pamiątkę tułactwa - nie tylko dla siebie, ale i rodziny" ${ }^{48}$. W rocznice wydania pierwszego numeru redakcja tygodnika „Polak w Iranie” składała periodykowi katolickiemu serdeczne życzenia, doceniając wytrwałość w trudzie wydawania podobnego pisma. „Po roku pracy - pisano - «Nasz Przyjaciel» może być szczerze zadowolony z pięknie spełnionego zadania" ${ }^{49}$. W grudniu 1944 r. periodyk pod tym samym tytułem zaczą być wydawany w Nairobi.

Wspólnota prawosławnych w Iranie również miała swoje pismo. Było nim „Ziarnko Prawosławne” wydawane przez Cywilne Duszpasterstwo Prawosławnych w Teheranie. Redaktorem naczelnym, sprawującym jednocześnie opiekę duchową nad ta grupa wiernych w Iranie, był pochodzacy z Wilna ks. Michał Bożerianow. Po ukazaniu się pierwszych numerów wraz z grupą wiernych

\footnotetext{
${ }^{45}$ Więcej na ten temat zob. O.S. Czarnik, Czasopismo „Skaut” na wschodnich szlakach polskiego wychodźstwa (1942-1946), w: W nieustannej trosce o polska diasporę. Tom studiów historycznych i politologicznych dedykowany Księdzu Arcybiskupowi Szczepanowi Wesołemu, red. R. Nir, M. Szczerbiński, K. Wasilewski, Gorzów Wielkopolski 2012, s. 319-340.

${ }^{46}$ M. Urzecka, Majsterkowanie w Żeńskiej Gromadzie Zuchów, „Wódz Zuchów. Jednodniówka Wodzów Gromad Zuchowych", I 1944.

${ }^{47}$ O.S. Czarnik, $W$ drodze do utraconej..., s. 248-249.

48 „Nasz Przyjaciel. Ulotka religijna dla Ludności Polskiej w Iranie” 1942, nr 6.

${ }^{49}$ Rocznica katolickiego pisma religijnego w Teheranie, „Polak w Iranie” 1943, nr 67.
} 
wyjechał do Tanzanii ${ }^{50}$. Pismo wychodziło jednak nadal w Iranie, przy czym przygotowywał je już ks. Wsiewołod Jeśkow. W sumie od stycznia 1942 r. do stycznia 1943 r. ukazało się 12 numerów, które informowały o życiu polskiego prawosławia w kraju i za granica ${ }^{51}$. W 1943 r. w obozie w Ahwazie zaczęto wydawać także periodyk dla dzieci i młodzieży, pt. „Promyk Prawosławny”. Choć pismo to ukazywało się przede wszystkim w Afryce Wschodniej, a jego irański epizod był krótki, to warto o nim wspomnieć choćby dlatego, że prawdopodobnie było to najdłużej wychodzące na emigracji pismo duchowieństwa prawosławnego ${ }^{52}$.

W kwietniu 1943 r. grupa żydowskich działaczy socjalistycznych Bundu wydała pierwszy numer swojego „Biuletynu”. W numerze styczniowym z 1944 r., opublikowanym zaraz po posiedzeniu wielkiej trójki w Teheranie, redakcja powątpiewała w możliwość prawdziwego porozumienia się przywódców państw kapitalistycznych i sowieckiego dyktatora. Krytycznie oceniano spotkanie w tak wasskim gronie osób, które miały decydować o szeregu kluczowych kwestii w życiu mniejszych narodów i państw. Pomimo lewicowo-socjalistycznego światopoglądu redakcja wyjątkowo krytycznie odnosiła się do polityczno-militarnych działań ZSRR. W styczniu 1944 r. pisano o stosowanej przez władze radzieckie metodzie faktów dokonanych, zajmowaniu ziem polskich i uznawaniu ich za swoje, a także chęci stworzenia w Polsce zależnych od siebie władz ${ }^{53}$.

Zupełnie inne stanowisko prezentował organ Zwiąku Patriotów Polskich na Środkowym Wschodzie - „Biuletyn Wolnej Polski”. Pierwszy numer ukazał się niedługo po wybuchu Powstania Warszawskiego, jednak temat ten w ogóle nie zaistniał na jego łamach ${ }^{54}$. Kolumny wypełnione były komunikatami o utworzeniu Polskiego Komitetu Wyzwolenia Narodowego, oświadczeniami Ludowego Komisariatu Spraw Zagranicznych ZSRR o stosunku tego państwa do Polski, informacjami o Krajowej Radzie Narodowej i utworzeniu Naczelnego Dowództwa Wojska Polskiego z Michałem Rolą-Żymierskim na czele. Kolejne numery przynosiły informacje o działaniach Armii Ludowej, życiorysach Edwarda Osóbki-Morawskiego, instalowaniu się nowej, zależnej

50 A. Mironowicz, Przyczynek do dziejów polskiego prawosławnego duszpasterstwa cywilnego na emigracji w czasie II wojny światowej, „Studia Polonijne” 2009, t. XXX, s. 205-210.

51 J. Grzybowski, Prasa i wydawnictwa Polskiego Autokefalicznego Kościoła Prawostawnego na obczyźnie podczas II wojny światowej, „Studia Interkulturowe Europy Środkowo-Wschodniej” 2013 t. VII, s. 5.

${ }^{52}$ Ibidem, s. 7-8.

53 J. Horn, Na progu 1944 roku, „Biuletyn” 1944, nr 1.

${ }^{54}$ Prawdopodobnie pierwszy numer pisma był już gotowy, zanim powstanie wybuchło. Do tematu powrócono w późniejszych numerach, zniekształcając jego obraz, przypisując wszelkie zasługi wyłącznie członkom Armii Ludowej. Więcej zob. M. Komuda, Stosunek propagandy komunistycznej do Powstania Warszawskiego na przyktadzie „Biuletynu Wolnej Polski”, w: Czy mamy coś nowego do powiedzenia? II wojna światowa w badaniach młodych historyków, red. s. M. Krupiecka, K. Utracka, Warszawa 2014, s. 205-221. 
od ZSRR władzy na wyzwalanych ziemiach ${ }^{55}$. Gazeta prezentowała klarowny, radykalnie antypolski światopogląd. Władze emigracyjne w Londynie nazywano „reakcja”, a działaczy Armii Krajowej i Narodowych Sił Zbrojnych oskarżano o pomoc wrogowi i nad „znęcaniem się na AL.-owcami i BCh-owcami” ${ }^{\text {. }}$.

Wśród Polaków, którzy dotarli do Iranu w 1942 r., znaleźli się także przedstawiciele inteligencji, artyści, literaci i ludzie nauki. Nie mając określonej perspektywy końca pobytu w Iranie, środowisko profesorów Uniwersytetu Stefana Batorego w Wilnie utworzyło Towarzystwo Studiów Irańskich ${ }^{57}$. Celem było prowadzenie prac naukowych $\mathrm{w}$ warunkach emigracyjnych, a także chęć zaznajomienia przybyłych do Iranu Polaków z ich tymczasowa ojczyzna, historia, kultura czy językiem perskim. W ramach utworzonego w październiku $1942 \mathrm{r}$. Towarzystwa prowadzono w poszczególnych obozach wykłady, pogadanki i kursy, organizowano wyjazdy studyjne, aby zapoznać się ze starożytnymi zabytkami Iranu. Współpracowano z irańskimi naukowcami. Chcąc przybliżyć Irańczykom historię i kulturę Polski, przygotowywano audycję $\mathrm{w}$ radiu teherańskim, a także pisano artykuły publikowane $\mathrm{w}$ irańskich gazetach ${ }^{58}$. Biuletyn Towarzystwa ukazywał się do 1947 r., był jednak drukowany już w Tel Awiwie.

Towarzystwo prowadziło także działalność wydawnicza. Obok różnego rodzaju skryptów i opracowań wydawano rocznik naukowy, pt. „Studia Irańskie”. W latach 1943-1945 ukazały się trzy obszerne objętościowo numery rocznika ${ }^{59}$. Pierwszy ujrzał światło dzienne w maju 1943 r. Stanowił pierwsza polska publikację naukowa, jaka pojawiła się w Iranie w czasie II wojny światowej. Autorzy przygotowali opracowania o geografii Iranu, aktualnych stosunkach gospodarczych tego państwa i jego pozycji w polityce światowej. Dodatkiem do tego tomu była aktualna mapa Iranu z naniesionymi nazwami w transkrypcji polskiej. Późną wiosną ukazał się drugi numer „Studiów Irańskich". Znalazły się w nim szkice o iranoznawstwie i iranologii, a także rozważania teoretyczne i przekłady z literatury perskiej. Ważną częścią było

${ }_{55}$ Na wolnej ziemi, „Biuletyn Wolnej Polski” 1944, nr 2-3; Na wyzwolonej ziemi, „Biuletyn Wolnej Polski” 1944, nr 6-7.

${ }_{56}$ Po tamtej stronie Wisty, Reakcja prowokuje, „Biuletyn Wolnej Polski” 1944, nr 12-13.

${ }^{57}$ Przewodniczącym był prof. Stanisław Kościałowski, wśród założycieli znalazł się także prof. Wiktor Sukiennicki, ważną rolę odgrywał też Franciszek Machalski, późniejszy sekretarz Towarzystwa. Więcej zob. J. Draus, Towarzystwo Studiów Irańskich w Teheranie w latach 1942-1945, „Roczniki Nauk Społecznych” 1986, t. XIII, z. 2, s. 59-72; M.T. Żuk, Towarzystwo Studiów Irańskich w Teheranie (1942-1945). Franciszek Machalski (1904-1979), „Rocznik Muzułmański” 2009, nr 7, s. 100-103; M. Kornat, Wiktor Sukiennicki (1901-1983) - prawnik, sowietolog, historyk, „Zeszyty Historyczne” 2001, z. 137.

58 AAN, Poselstwo RP w Teheranie, 38, Sprawozdanie z działalności Towarzystwa Studiów Irańskich (TSiR) w Teheranie od dnia 20 XI 1942 r. do 20 III 1944 r., k. 151-155.

${ }^{59}$ Pierwsze dwa numery miały ponad 160 stron, trzeci blisko 300 stron, przy czym ok. 100 stron zajął wykaz poloniców irańskich. Zob. M. Gołaszewska, S. Kościałowski, Polonica bibliograficzne irańskie z lat 1942-1943-1944, „Studia Irańskie” 1945, t. III, s. 206-291. 
sprawozdanie z dotychczasowej działalności Towarzystwa Studiów Irańskich. Ostatni numer rocznika wyszedł jesienią 1945 r. W całości poświęcony był kulturze i obyczajowości perskiej. Znalazły się w nim artykuły o języku perskim, zwyczajach współczesnego Iranu, pozycji kobiety w Iranie, a także zabobonach i okultyzmie. Już po wojnie znany krakowski profesor, turkolog, oceniał przydatność tego pisma: „Każdy tom przynosi szereg cennych artykułów i rozpraw, wydatnie wzbogacających naszą literaturę iranistyczną [...] stanowia one bogaty wkład do naszego piśmiennictwa"60.

Niezbędnych jest kilka ogólnych uwag technicznych dotyczących polskich czasopism wydawanych w Iranie w latach 1942-1945. Część wymienionych tytułów przygotowywano na maszynie do pisania, następnie powielano. Niekiedy formę tę uatrakcyjniano odręcznymi ilustracjami. Publikacje powielane dotyczyły przede wszystkich tych przygotowywanych w Isfahanie, a także do 1943 r. w Teheranie. Wydawnictwa polskie drukowane były w zdecydowanej większości w trzech teherańskich drukarniach: „Czap”, „Medzlis” i Banku „Melli”. Artykuły i komunikaty prawie zawsze nie zawierały polskich czcionek, co niekiedy utrudnia lekturę poszczególnych pism. W wypadku tygodnika „Polak w Iranie” pod koniec 1943 r. dział kulturalno-oświatowy MPiOS dostarczył do drukarni „Medzlis” czcionki polskie, co wyraźnie poprawiło wygląd gazety. Nie zmienia to jednak faktu, że gazety składane były w drukarniach przez irańskich zecerów, którzy nie znali języka polskiego, co powodowało, że niejednokrotnie mamy do czynienia z różnej wagi błędami językowymi.

Jeżeli chodzi o stronę merytoryczna, to wielką słabością polskiego czasopiśmiennictwa w Iranie była uderzająca poprawność polityczna. Warunki, w których przygotowywano poszczególne tytuły prasowe, nie pozwalały na swobodne wyrażanie myśli i poglądów, zwłaszcza dotyczących spraw międzynarodowych. Już od 1942 r. każdy materiał prasowy publikowany w polskich gazetach podlegał cenzurze ${ }^{61}$. Dbali o to zarówno Brytyjczycy, jak i władze polskie. Najbardziej wrażliwą kwestię stanowiły stosunki ze Związkiem Radzieckim. W owym czasie był to sojusznik w walce z Niemcami, jednocześnie wszyscy przybyli do Iranu Polacy właśnie z rąk Rosjan, a nie Niemców doświadczyli wszelkich okrucieństw wojny. Brytyjczycy, a także władze polskie, byli szczególnie wyczuleni, żeby nie dopuszczać do zaogniania sytuacji, zwłaszcza że ZSRR wraz z Wielką Brytanią od 1941 r. okupował Iran ${ }^{62}$.

${ }^{60}$ W. Zajączkowski, Polska działalność orientalistyczna na Wschodzie $w$ latach 1942-1946, „Przegląd Orientalistyczny” 1948, z. 1, cyt. za: M.A. Supruniuk, op. cit., s. 61-62.

${ }^{61}$ Wyjatek stanowiły informacje z brytyjskiej i irańskiej agencji prasowej, które wcześniej już były sprawdzane. AAN, Poselstwo RP w Teheranie, 66, Pismo do Poselstwa w sprawie cenzurowania tygodników „Zew” i „Polak w Iranie”, Teheran, 5 IX 1942, k. 61.

${ }_{62}$ Więcej zob. R.A. Stewart, Sunrise at Abadan. The British and Soviet invasion of Iran. 1941, New York 1988; J.B. McNabb, A Military History of the Modern Middle East, Santa Barbara-Denver 2017, s. 118-120. 
Jednym z charakterystycznych przykładów takiej sytuacji był opublikowany w tygodniku „Zew” rozkaz Andersa, w którym generał mówił m.in. o konieczności zemsty za poległych, którzy spoczywali rozsiani po świecie od Afryki po Syberię ${ }^{63}$. Słowa te wywołały niezwykłą nerwowość u władz polskich. Minister Stanisław Kot w liście do premiera Władysława Sikorskiego pisał, że zdanie o zemście jest niedopuszczalne, ponieważ „Budzi ono przykre komentarze u niektórych Anglików, a zwłaszcza u Sowietów”. Rozkaz, powołujący do życia Armię Polską na Wschodzie, miał być przedrukowany m.in. w tygodniku „Polak w Iranie”. Kot sugerował wstrzymanie numeru i dodrukowanie wyjaśnienia, że winę za śmierć rodaków, których groby sa rozsiane od Afryki po Syberię, ponoszą wyłącznie Niemcy. Nie chciano dopuścić do swobodnej interpretacji tych słów. Parę dni później Kot w kolejnym liście pisał o planie dojścia z Brytyjczykami do porozumienia. W zamian za unikanie antyradzieckich treści w polskich tytułach prasowych Brytyjczycy mieli przestać przedstawiać pobyt tysięcy Polaków w ZSRR jako dobrowolne schronienie ludności przed zbrodniami niemieckimi ${ }^{64}$.

Innym problemem, który wpływał bezpośrednio na polski rynek prasowy w Iranie, były spory polityczne istniejące w łonie polskiego wychodźstwa. Nie miał znaczenia fakt, że tysiące Polaków doznało niewyobrażalnych krzywd ze strony okupantów, przeżyło gehennę w Związku Radzieckim, znalazło się ostatecznie w dalekim od domu i ojczyzny Iranie. Wewnętrzna walka polityczna trwała i tam. Sam fakt, że w Iranie wychodziła duża liczba polskich tytułów prasowych, nie oznaczał jeszcze, że były one znane wśród polskiego wychodźstwa. Drobnym, ale charakterystycznym przykładem omawianego w artykule zagadnienia jest postawa Franciszka Halucha, delegata MPiOS na Środkowym Wschodzie. Ten członek PPS, który uzyskał na początku $1943 \mathrm{r}$. ogrom władzy, nie wahał się konfiskować poszczególnych - przedstawiających inny punkt widzenia - tytułów prasowych, zakazywał też w obozach polskich kolportażu jakiejkolwiek innej prasy niż ta wydawana przez MPiOS ${ }^{65}$.

Poniżej przedstawione zostało zestawienie wszystkich znanych tytułów prasowych, nie wyłączając komunikatów i jednodniówek ${ }^{66}$, o których wiadomo, że ukazały się w latach 1942-1945 w polskich ośrodkach uchodźczych w Teheranie, Isfahanie i Ahwazie. Zestawienie zawiera także w miarę możliwości precyzyjne dane o czasie, w którym dany tytuł wychodził, miejscu jego wydania, a także redaktorach.

${ }^{63}$ Rozkaz Dowódcy Armii Polskiej na Wschodzie gen. Wtadystawa Andersa, „Zew” 1942, nr 13.

${ }^{64}$ Archiwum Instytutu i Muzeum im. gen. Sikorskiego, PRM. 80, Listy ministra Stanisława Kota do premiera Władysława Sikorskiego, Londyn, 24 IX 1942 r. i 27 IX 1942 r., k. 29, 30, 43.

${ }^{65}$ K. Śliwak, Delegatura Ministerstwa Pracy..., s. 263.

${ }^{66}$ Jednodniówki to specyficzne wydawnictwa okolicznościowe posiadajace formę wydawnicza charakterystyczną dla czasopism, niemniej jednak przez niektórych badaczy za czasopisma nieuznawane. Więcej zob. Encyklopedia wspótczesnego bibliotekarstwa polskiego, Wrocław 1976, s. 146; H. Wojtysiak, Jednodniówki jako osobliwy rodzaj wydawnictw ciagtych, „Biuletyn EBIB” 2012, nr 2. 
Wykaz polskich tytułów prasowych, które ukazały się w Iranie w latach 1942-1945

\begin{tabular}{|c|c|c|c|}
\hline $\begin{array}{l}\text { TYTUL } \\
\text { PISMA }\end{array}$ & $\begin{array}{c}\text { DATY } \\
\text { UKAZYWANIA SIE }\end{array}$ & $\begin{array}{l}\text { MIEJSCE } \\
\text { WYDANIA }\end{array}$ & $\begin{array}{l}\text { REDAKTOR } \\
\text { NACZELNY }\end{array}$ \\
\hline „Biuletyn” (Bundu) & IV 1943 - VIII 1944 & Teheran & - \\
\hline $\begin{array}{l}\text { „Biuletyn Polskiego } \\
\text { Czerwonego Krzyża” }\end{array}$ & VIII-IX 1945 & Teheran & - \\
\hline $\begin{array}{l}\text { „Biuletyn Polskiej Agencji } \\
\text { Polpress w Teheranie” }\end{array}$ & I-V 1945 & - & - \\
\hline „Biuletyn Wolnej Polski” & VIII 1944 - V 1947 & $\begin{array}{c}\text { Teheran/ Tel } \\
\text { Awiw }\end{array}$ & - \\
\hline $\begin{array}{c}\text { „Biuletyn Zespołu Pracy nad } \\
\text { Odbudową Polski” }\end{array}$ & VIII 1943 - I 1945 & Teheran & Konstanty Rdułtowski \\
\hline „Bulletin D’Information” & XI 1944 - VI 1945 & Teheran & dr Jerzy Lenczowski \\
\hline $\begin{array}{l}\text { "Chłop i Państwo" - } \\
\text { jednodniówka }\end{array}$ & 13 VI 1943 & Teheran & \\
\hline „Demawend” & IV-V 1944 & Teheran & $\begin{array}{c}\text { Wanda Szuszkiewicz- } \\
\text {-Gorszczyk, Halina Zięciak }\end{array}$ \\
\hline $\begin{array}{c}\text { „Głos Uchodźcy Polskiego } \\
\text { w Iranie” }\end{array}$ & IX-XI 1944 & Teheran & \\
\hline $\begin{array}{l}\text { "Gwiazda Betlejemska" - } \\
\text { jednodniówka }\end{array}$ & 24 XII 1944 & Teheran & ks. Władysław Słapa \\
\hline $\begin{array}{l}\text { „Jednodniówka Stronnictwa } \\
\text { Ludowego w Iranie" }\end{array}$ & I 1945 & $\begin{array}{l}\text { Ahwaz, } \\
\text { Isfahan, } \\
\text { Teheran }\end{array}$ & - \\
\hline $\begin{array}{l}\text { „Komunikat Delegatury } \\
\text { Opieki nad Uchodźcami” }\end{array}$ & VII-XII 1945 & Teheran & - \\
\hline $\begin{array}{c}\text { „Komunikat Poselstwa RP } \\
\text { w Teheranie” }\end{array}$ & $1942-1944$ & Teheran & $\begin{array}{l}\text { dr Wiktor Weintraub, Leon } \\
\text { Kryj, Michał Tyszkiewicz }\end{array}$ \\
\hline $\begin{array}{l}\text { „Komunikat Radiowy dla } \\
\text { Uchodźców w Teheranie” }\end{array}$ & IV-V 1942 & Teheran & dr Wiktor Weintraub \\
\hline „La Nouvelle Europe” & I 1943 - VI 1945 & & dr Jerzy Lenczowski \\
\hline „Lachestan” - jednodniówka & $6 \times 1942$ & & \\
\hline „My” & $1943-1945$ & Isfahan & $\begin{array}{c}\text { Mieczysław Kotlicki, } \\
\text { Halina Zięciakowa, Józefa } \\
\text { Zimmerman, Maria } \\
\text { Krzyżanowska }\end{array}$ \\
\hline „Name-Je-Lechistani” & IX 1942 - V 1943 & Teheran & dr Jerzy Lenczowski \\
\hline „Nasz Przyjaciel” & XII 1942 - V 1944 & Teheran & Władysław Słapa \\
\hline $\begin{array}{c}\text { „Nauczyciel i Uczeń w Iranie” } \\
\text { - jednodniówka }\end{array}$ & 1944 & Teheran & - \\
\hline „Orzeł Biały” & IX-X 1942 & - & Roman Hausner \\
\hline „Piechur w Kermie” & $\begin{array}{l}\text { II } 1942-1943 \\
\text { gazetka ścienna }\end{array}$ & - & - \\
\hline
\end{tabular}




\begin{tabular}{|c|c|c|c|}
\hline $\begin{array}{l}\text { TYTUL } \\
\text { PISMA }\end{array}$ & $\begin{array}{c}\text { DATY } \\
\text { UKAZYWANIA SIE }\end{array}$ & $\begin{array}{l}\text { MIEJSCE } \\
\text { WYDANIA }\end{array}$ & $\begin{array}{l}\text { REDAKTOR } \\
\text { NACZELNY }\end{array}$ \\
\hline „Polak w Iranie” & VI 1942 - V 1944 & Teheran & $\begin{array}{c}\text { Bronisław Skalak, Tadeusz } \\
\text { Ehrenberg, Michał } \\
\text { Tyszkiewicz, Roman Boski }\end{array}$ \\
\hline „Polish News Bulletin” & VI 1943 - I 1945 & Teheran & dr Jerzy Lenczowski \\
\hline „Polska Nowojagiellońska” & II, VIII 1943 & - & Tadeusz Dzieduszycki \\
\hline $\begin{array}{l}\text { „Polski Czerwony Krzyż. } \\
\text { Delegatura w Teheranie” }\end{array}$ & VIII-IX 1945 & Teheran & - \\
\hline „Promyk Prawosławny” & I 1943 - VII 1944 & $\begin{array}{l}\text { Teheran/ } \\
\text { Tanger }\end{array}$ & - \\
\hline „Przegląd Polski” & I-III 1943 & & Konstanty Rdułtowski \\
\hline $\begin{array}{l}\text { „Salus Reipublicae Suprema } \\
\text { Lex” - jednodniówka }\end{array}$ & V 1943 & Teheran & - \\
\hline „Słowo Polskie” & XII 1942 - IV 1943 & Teheran & Stefan Bros \\
\hline „Studia Irańskie” & $1943-1945$ & Teheran & Stanisław Kościałowski \\
\hline „Szkoła na Obczyźnie” & IV 1945 & Isfahan & $\begin{array}{c}\text { Henryk Piekarski, Józefa } \\
\text { Zimmerman }\end{array}$ \\
\hline $\begin{array}{l}\text { "Teherańskie Fraszki dla } \\
\text { Żołnierskiej Igraszki” }\end{array}$ & 1942 & Teheran & - \\
\hline $\begin{array}{c}\text { „Wiadomości Radia } \\
\text { Brytyjskiego" }\end{array}$ & - & Ahwaz & - \\
\hline „Wiadomości Radiowe” & $1944-1945$ & Ahwaz & Edward Rumun \\
\hline „Wieści z Polski” & X-XII 1945 & - & - \\
\hline „Wódz Zuchów” & $\begin{array}{c}\text { I } 1944- \\
\text { jednodniówka }\end{array}$ & - & hm. Zdzisław Peszkowski \\
\hline $\begin{array}{l}\text { „Zespół Pracy nad Odbudowa } \\
\text { Polski” }\end{array}$ & $1942-1943$ & - & Konstanty Rdułtowski \\
\hline „Zew” & VII-X 1942 & Teheran & $\begin{array}{c}\text { Eugenia Duszyńska, } \\
\text { W.L. Evert, L. Naimski }\end{array}$ \\
\hline $\begin{array}{c}\text { „Ze wspomnień naszej klasy” } \\
\text { - jednodniówka }\end{array}$ & II 1945 & Isfahan & - \\
\hline „Ziarnko Prawosławne” & I 1943 - VII 1944 & Teheran & $\begin{array}{l}\text { Michał Bożerianow, } \\
\text { Wsiewołod Jeskow }\end{array}$ \\
\hline
\end{tabular}

Źródło: Archiwum Akt Nowych, Towarzystwo Studiów Irańskich; J. Bielatowicz, Czasopiśmiennictwo polskie na Śr. Wschodzie, „Orzeł Biały”, 14 V 1944; M. Dunajówna, Polskie wydawnictwa w Iranie w okresie ostatniej wojny, „Bibliotekarz” 1947, nr 9-10; M. Gołaszewska, S. Kościałowski, Polonica bibliograficzne irańskie z lat 1942-1943-1944, „Studia Irańskie” 1945, t. III; J. Kowalik, Bibliografia czasopism polskich wydanych poza granicami Kraju od września 1939 roku. T. 1-4, Lublin 1976; idem, Bibliografia czasopism polskich wydanych poza granicami Kraju od września 1939 roku. Suplement do tomów 1-4. T. 5, Lublin 1988; idem, Czasopiśmiennictwo, w: Literatura polska na obczyźnie 1940-1960, red. T. Terlecki, t. II, Londyn 1965; Polacy w Iranie 1942-1945, t. I: Antologia, oprac. A.K. Kunert, Warszawa 2002. 
Kilka lat pobytu Polaków w Iranie przyniosło obszerna spuściznę wydawnicza. W latach 1942-1945 ukazało się tam ok. 300 różnego rodzaju druków polskich zawierających: książki, opracowania, plakaty, ulotki, broszury, zaproszenia, afisze, odezwy, regulaminy, zarządzenia, kalendarze, katalogi, czytanki, pocztówki, modlitewniki, legitymacje, reklamy, mapy czy plany miast. Ściślej rzecz ujmując, wielokrotnie były to nie tyle druki, co odbitki wykonane na powielaczu. W tej dużej liczbie ok. 10\% przypada na periodyki prasowe $^{67}$. Nie mamy jednak pewności, że to kompletna lista. Nawet zestawienie przygotowywane w 1944 r. przez Melanię Gołaszewską i Stanisława Kościałowskiego zawiera wiele pytań i nieścisłości. Autorzy wymieniaja niekiedy określone tytuły - zwłaszcza te o wyjątkowo krótkim żywocie zaznaczając, że nie widzieli ich na oczy.

Niezależnie od powyższych uwag nie ma wątpliwości, że lista periodyków jest wyjątkowo długa. Nie ryzykując wiele, można ocenić, że ich liczba znacznie przewyższała potrzeby czytelnicze Polaków w Iranie. Świadomy tego faktu był m.in. prof. Franciszek Machalski, sekretarz Towarzystwa Studiów Irańskich, który pisał: „To, o czym się mówi w stu czasopismach, można doskonale powiedzieć w dziesięciu. Toteż gdziekolwiek na kuli ziemskiej zbierze się garstka Polaków, powstaje jedno lub więcej czasopism”68. Należy zakładać, iż poszczególne ugrupowania polityczne, organizacje, grupy czy stowarzyszenia liczyły, że ich wydawnictwa dotrą do szerokich grup odbiorców, będą okazją do zamanifestowania swoich poglądów, szansą przekonania do swoich racji. Tak jednak się nie stało. Szereg tytułów prasowych, pomimo początkowo ambitnych założeń, błyskawicznie znikał z irańskiego rynku prasowego. Gdyby nie prowadzona na bieżąco, na miejscu, w warunkach emigracyjnych praca badaczy skupionych wokół Towarzystwa Studiów Irańskich, o większości wydawnictw nic dziś nie wiedzielibyśmy. Zaledwie kilka spośród kilkudziesięciu tytułów oddziaływało na inne polskie ośrodki na Bliskim Wschodzie, o kilku z nich słyszano w Wielkiej Brytanii czy Stanach Zjednoczonych.

Nie zmienia to jednak faktu, że wszystkie z nich sa dziś interesujacym świadectwem sytuacji, która nigdy wcześniej ani nigdy później nie miała miejsca w historii. Sytuacji, w której Bliski Wschód, w szczególności Iran, stał się największym skupiskiem polskiego wychodźstwa. Nigdy dotąd i nigdy później w tej części świata nie przebywało tak wielu Polaków. Zachowane gazety i czasopisma przynoszą nam obraz życia tysięcy uchodźców w dalekim i obcym kulturowo regionie - ich życie codzienne, troski, problemy, rozrywki, ale także kłótnie i spory polityczne, których nie udało się uniknąć.

${ }^{67}$ J. Kowalik, Czasopiśmiennictwo, w: Literatura polska na obczyźnie 1940-1960, red. T. Terlecki, t. II, Londyn 1965, s. 423; M. Dunajówna, Polskie wydawnictwa w Iranie w okresie ostatniej wojny, „Bibliotekarz” 1947, nr 9-10, s. 148-149.

${ }^{68}$ F. Machalski, Z ziemi perskiej do Polski. Wybór tekstów, wstęp i oprac. K. i K. Paraskiewicz, Kraków 2016. 


\section{Streszczenie}

Polacy nie wiedzieli, jak długo przyjdzie im przebywać na terenie Iranu. Starali się w nietypowych warunkach żyć normalnie albo przynajmniej stwarzać pozory normalnego życia. Jednym z przejawów tego zjawiska - obok organizowania oświaty, życia kulturalnego czy naukowego - była polska publicystyka. Natychmiast po tym, jak pierwsi wychodźcy ze Związku Sowieckiego dotarli do Iranu, pojawiły się pierwsze biuletyny i komunikaty przygotowywane w języku polskim. Z czasem zaczęły ukazywać się gazety. Niektóre były charakterystycznymi efemerydami, które reprezentowały wyjątkowo waską grupę odbiorców i ukazywały się bardzo krótko, inne natomiast wychodziły regularnie i stanowiły dla Polaków istotne źródło informacji o sytuacji w okupowanej Polsce, działaniach wojennych na świecie i o samym Iranie, w którym przyszło żyć czytelnikom. W latach 1942-1945 w Iranie ukazało się kilkadziesiąt polskich gazet, biuletynów i jednodniówek.

\section{Polish Press in Iran in 1942-1945}

The Poles did not know for how long they would be in Iran. Despite unusual circumstances, they tried to live a normal life or at least to make an impression of normal life. One of the symptoms of this phenomenon was - apart from organising educational, cultural, and scientific life - Polish journalism. Immediately upon the arrival of first refugees from the Soviet Union in Iran, first bulletins and press releases appeared, written in the Polish language. In time, first Polish journals were being published. Some of them were characteristic ephemerides, which appeared for a very short time and had a narrow audience, while others were issued regularly and made an important source of news for Polish people about the situation in occupied Poland, world war operations, and Iran itself, the country where they had to live. In 1942-1945 in Iran a few dozens of Polish newspapers, bulletins, and daily special issues appeared.

\section{Bibliografia}

Chojnacki P., Mesjanizm Drugiej Wielkiej Emigracji. Wielkopolski, Dzieduszycki i Nałęcz, „Pressje” 2012, t. XXX/XXXI.

Czapski J., Relacja o pracy Biura Propagandy i Kultury w 1942 r., „Zeszyty Historyczne” (Paryż) 2001, z. 138.

Czarnik O.S., Czasopismo „Skaut” na wschodnich szlakach polskiego wychodźstwa (1942-1946), w: W nieustannej trosce o polska diasporę. Tom studiów historycznych i politologicznych dedykowany Księdzu Arcybiskupowi Szczepanowi Wesołemu, red. R. Nir, M. Szczerbiński, K. Wasilewski, Gorzów Wielkopolski 2012.

Draus J., Oświata i nauka polska na Bliskim i Środkowym Wschodzie 1939-1950, Lublin 1993.

Draus J., Towarzystwo Studiów Irańskich w Teheranie w latach 1942-1945, „Roczniki Nauk Społecznych" 1986, t. XIII, z. 2.

Dunajówna M., Polskie wydawnictwa $w$ Iranie $w$ okresie ostatniej wojny, „Bibliotekarz” 1947, nr 9-10.

Duraczyński E., Układ Sikorski-Majski, „Dzieje Najnowsze” 1987, nr 1.

Dzieje harcerstwa na obczyźnie w latach 1912-1992. Materiaty z konferencji naukowej odbytej w dniach 29-30 maja 1992 r. w Rogach k. Gorzowa Wlkp., red. M. Szczerbiński, Gorzów Wielkopolski 1992.

Górszczyk M.J., Szkice emigracyjne. Rumunia. Iran. Palestyna. Egipt, Warszawa 1948.

Grzybowski J., Prasa i wydawnictwa Polskiego Autokefalicznego Kościoła Prawostawnego na obczyźnie podczas II wojny światowej, „Studia Interkulturowe Europy Środkowo-Wschodniej” 2013, t. VII. 
Huntingdon E., Nie wyrównany rachunek. Wspomnienia, Warszawa 1994.

Isfahan. Miasto polskich dzieci, red. I. Beaupré-Stankiewicz, D. Waszczuk-Kamieniecka, J. Lewicka-Howells, Londyn 1987.

Kantecki A., Szkolnictwo polskie w Iranie w latach II wojny światowej, „Nadwarciański Rocznik Historyczno-Archiwalny" 2003, nr 10.

Komuda M., Stosunek propagandy komunistycznej do Powstania Warszawskiego na przykładzie „Biuletynu Wolnej Polski”, w: Czy mamy coś nowego do powiedzenia? II wojna światowa w badaniach młodych historyków, red. s. M. Krupiecka, K. Utracka, Warszawa 2014.

Kornat M., Wiktor Sukiennicki (1901-1983) - prawnik, sowietolog, historyk, „Zeszyty Historyczne" 2001, z. 137.

Kowalik J., Bibliografia czasopism polskich wydanych poza granicami Kraju od września 1939 roku. Suplement do tomów 1-4. T. 5, Lublin 1988.

Kowalik J., Bibliografia czasopism polskich wydanych poza granicami Kraju od września 1939 roku. T. 1-4, Lublin 1976.

Kukla W., Skaut. Czasopismo Zwiazku Harcerstwa Polskiego na Wschodzie 1942-1946, „Skaut. Harcerskie Pismo Historyczne” 2007, nr 3.

Literatura polska na obczyźnie 1940-1960, red. T. Terlecki, t. II, Londyn 1965.

Machalski F., Z ziemi perskiej do Polski. Wybór tekstów, wstęp i oprac. K. i K. Paraskiewicz, Kraków 2016.

Mironowicz A., Przyczynek do dziejów polskiego prawosławnego duszpasterstwa cywilnego na emigracji w czasie II wojny światowej, „Studia Polonijne” 2009, t. XXX.

Ney-Krwawicz M., „Polak w Iranie” o młodych i najmłodszych uchodźcach polskich z ZSRR $w$ Iranie $w$ latach 1942-1944, „Dzieje Najnowsze” 2014, nr 1.

Ożarowski R., Bliski Wschód w rozważaniach pojęciowych i geograficznych, „Gdańskie Studia Międzynarodowe" 2009, t. VII, nr 1-2.

Pietrzak J., Polscy uchodźcy na Bliskim Wschodzie w latach II wojny światowej. Ośrodki, instytucje, organizacje, Łódź 2012.

Polacy w Iranie 1942-1945, t. I: Antologia, oprac. A.K. Kunert, Warszawa 2002.

Rdułtowski K., Notatki z wygnania, oprac. S. Ciesielski, Warszawa-Wrocław 1996.

Truchanowicz T., Zwiazek Harcerstwa Polskiego na Wschodzie. Z dziejów harcerstwa na obczyźnie 1940-1946, Warszawa 1987.

Walaszczyk K., Środkowy Wschód w latach II wojny światowej. Relacje i dziatania polskich placówek dyplomatycznych i konsularnych w Iranie, Iraku i Afganistanie, Toruń 2012.

Wierzbicki M., Zwiazek Harcerstwa Polskiego działajacy poza granicami kraju jako przedmiot badań naukowych, w: Emigracyjne miscellanea. Studia z dziejów polskiej emigracji politycznej 1939-1990, red. S. Łukasiewicz, Warszawa 2017.

Wróbel J., Uchodźcy polscy ze Zwiazku Sowieckiego 1942-1950, Łódź 2003.

Zajaczkowski W., Polska dziatalność orientalistyczna na Wschodzie w latach 1942-1946, „Przegląd Orientalistyczny” 1948, z. 1.

Żuk M.T., Towarzystwo Studiów Irańskich w Teheranie (1942-1945). Franciszek Machalski (1904-1979), „Rocznik Muzułmański” 2009, nr 7.

Biogram: Pawel Szulc - dr; w Instytucie Historii PAN obronił pracę Polskie Radio Szczecin $w$ systemie politycznym Polski $w$ latach 1945-1989; pracownik Oddziałowego Biura Badań Historycznych IPN w Szczecinie. Autor monografii Propaganda stalinowska na Pomorzu Zachodnim. Zainteresowania badawcze koncentrują się wokół zagadnienia propagandy PRL, a także funkcjonowania środków masowego przekazu w powojennej Polsce. E-mail: paw.szulc@interia.pl. 